\title{
ALIAS MANAGER USED IN DATABASE DESKTOP STUDI CASE DB DEMOS
}

\author{
Arie Setya Putra \\ 0201028701 \\ University Of Mitra Indonesia \\ ariesetyaputra@umitra.ac.id
}

\begin{abstract}
Academic achievement is one of the major subjects in the educational researches. Academic achievement is defined as the outcomes of the education. Preventing students from failure is related with identifying the factors affecting the achievement. By defining the important factors affecting the students' achievement, failure can be under controlled [Ozguven, 1974]. Education is a complex process and many factors directly or indirectly may affect achievement. Besides, it is difficult to properly define the major factors influencing students' achievement. Although researchers have identified several factors affecting the student achievement, there are still some arguments about them. Some researchers attribute the student's achievement to the school; others indicate that the school makes little impact on academic outcome. Other researchers say that the effective teacher is the only one who can play the main role in terms of student progress. All the factors such as teacher, school context, classroom context and the community around the school contribute or impact student's achievement somehow [Harris, 1999]. In all these thoughts, we can see that there are three common factors affecting the students' achievement. Factors related with teachers, students and lastly environment. All these factors are affective on the students' grade more or less. In our research, we handle the students' perspective and search for the factors affecting the students' achievement in their demographic items such as age, sex, and their academic background such as high school type, grade, University Entrance score, their families' social and economic status, income, housing, computer knowledge skills and social behaviors and mannerism. The aim of this study is to find out what kinds of factors have effects on students' exam success among the students at School of Transportation and Logistics by using the path analysis.
\end{abstract}

Keywords: Object Pascal Language, Manual Report 


\section{A. INTRODUCTION}

Section Class Ke $\mathbf{n}$ membahas

mengenai i cloud system ...dst tambahkan gambar untuk memperkuat penjelasan Gunakan Minimal 600 kata )

B. LITERATURE REVIEW

Pembahasan umum Referensi terkait ....( minimal 150 kata )

C. RESULT

Hasil ....( minimal 150 kata )

D. CONCLUSION

Kesimpulan dari materi ini adalah ....( minimal 150 kata )

E. ACKNOWLEDGEMENT

University Of Indonesia University Of Mitra Indonesia

Telkom University

University Of Mellbourne

Saitama University 


\section{F. REFERENCES}

[1] A. S. Putra, H. Sukri, and K. Zuhri, "Sistem Monitoring Realtime Jaringan Irigasi Desa (JIDES) Dengan Konsep Jaringan Sensor Nirkabel," IJEIS (Indonesian J. Electron. Instrum. Syst., vol. 8, no. 2, pp. 221-232.

[2] D. P. Sari, O. M. Febriani, and A. S. Putra, "Perancangan Sistem Informasi SDM Berprestasi pada SD Global Surya," in Prosiding Seminar Nasional Darmajaya, 2018, vol. 1, no. 1, pp. 289-294.

[3] A. S. Putra, "Paperplain: Execution Fundamental Create Application With Borland Delphi 7.0 University Of Mitra Indonesia," 2018.

[4] A. S. Putra, D. R. Aryanti, and I. Hartati, "Metode SAW (Simple Additive Weighting) sebagai Sistem Pendukung Keputusan Guru Berprestasi (Studi Kasus: SMK Global Surya)," in Prosiding Seminar Nasional Darmajaya, 2018, vol. 1, no. 1, pp. 85-97.

[5] A. S. Putra and O. M. Febriani, "Knowledge Management Online Application in PDAM Lampung Province," in Prosiding International conference on Information Technology and Business (ICITB), 2018, pp. 181-187.

[6] A. S. Putra, O. M. Febriani, and B. Bachry, "Implementasi Genetic Fuzzy System Untuk Mengidentifikasi Hasil Curian
Kendaraan Bermotor Di Polda Lampung," SIMADA (Jurnal Sist. Inf. dan Manaj. Basis Data), vol. 1, no. 1, pp. 21-30, 2018.

[7] A. S. Putra, "2018 Artikel Struktur Data, Audit Dan Jaringan Komputer," 2018.

[8] O. M. Febriani and A. S. Putra, "Sistem Informasi Monitoring Inventori Barang Pada Balai Riset Standardisasi Industri Bandar Lampung," J. Inform., vol. 13, no. 1, pp. 90-98, 2014. 